\title{
APLIKASI PARTIAL LEAST SQUARE STRUCTURAL EQUATION MODELLING UNTUK MENILAI FAKTOR PENCEMARAN AIR KALI SURABAYA
}

\section{APPLICATION OF PARTIAL LEAST SQUARE STRUCTURAL EQUATION MODELLING FOR ASSESSING THE WATER POLLUTION FACTOR OF KALI SURABAYA}

\author{
Adam Rus Nugroho $^{* 1}$, Ali Masduqi ${ }^{1)}$, Bambang Widjanarko Otok ${ }^{2)}$ \\ ${ }^{1)}$ Jurusan Teknik Lingkungan Institut Teknologi Sepuluh Nopember, Surabaya \\ ${ }^{2)}$ Jurusan Statistika Institut Teknologi Sepuluh Nopember, Surabaya \\ ${ }^{* *}$ E-mail: adam12@mhs.enviro.its.ac.id
}

\begin{abstract}
Abstrak
Pencemaran yang terjadi pada air Kali Surabaya disebabkan oleh beberapa faktor. Namun belum dapat dipastikan faktor pencemaran yang signifikan. Penelitian ini bertujuan untuk menilai pengaruh dan signifikansi dari faktor pencemaran air Kali Surabaya. Beberapa faktor pencemaran akan diprediksi pengaruhnya terhadap tingkat pencemaran Kali Surabaya. Kondisi hulu, kualitas air limbah domestik, dan persepsi masyarakat adalah variabel eksogen (variabel prediktor) yang diprediksi akan mempengaruhi variabel endogen (variabel respon), yaitu tingkat pencemaran Kali Surabaya. Penelitian ini menggunakan teknik Partial Least Square - Structural Equation Modeling (PLS-SEM) dengan menggunakan program SmartPLS 2.0 M3. Evaluasi outer model dan inner model menghasilkan model matematis berupa persamaan struktural sebagai berikut: tingkat pencemaran $=0,215 \times$ kondisi hulu + $0,466 \times$ kualitas air limbah domestik $-0,129 \times$ persepsi masyarakat. Hasil penelitian ini menyatakan bahwa faktor pencemaran Kali Surabaya yang signifikan adalah kondisi hulu sungai dengan nilai tstatistik sebesar 2,24.
\end{abstract}

Kata kunci: faktor pencemaran, Kali Surabaya, partial least square, structural equation modelling

\begin{abstract}
Water pollution occurred in Surabaya River due to several factors. However, significant factors of pollution not determined yet. This study aims to assess the influence and significance of water pollution factor of Surabaya River. Several factors will be predicted their effects on pollution levels of Surabaya River. Conditions of upstream water, domestic waste water quality, and communities perception are exogenous variables (predictor variables) which predicted to affect endogenous variable (response variable), namely pollution level of Surabaya River water. This study used the technique of Partial Least Square - Structural Equation Modeling (PLS-SEM) using computer program SmartPLS 2.0 M3. Evaluation of the outer and inner model produce a mathematical model as structural equation as follows: pollution level $=0.215 \times$ conditions of upstream water $+0.466 \times$ domestic wastewater quality $)-(0.129 \times$ communities perception). The results of this study indicate that significant factor of Surabaya River water pollution is the condition of upstream water with the tstatistic as large as 2.24 .
\end{abstract}

Keywords: partial least square, pollution factor, structural equation modelling, Surabaya River 


\section{PENDAHULUAN}

Kali Surabaya yang merupakan hilir dari Sungai Brantas merupakan sungai yang sangat penting karena Kali Surabaya bersifat multifungsi dalam menunjang pembangunan daerah, yaitu sebagai sumber air baku PDAM, industri, pertanian dan sarana rekreasi. Penelitian selama tujuh tahun terakhir menunjukkan kualitas air Kali Surabaya masih belum memenuhi persyaratan sebagai air baku bagi instalasi penjernihan air minum (Masduqi dan Apriliani, 2008). Laporan Status Lingkungan Hidup Kota Surabaya Tahun 2011 menyatakan bahwa parameter pencemaran air secara keseluruhan di sungai-sungai Kota Surabaya menunjukkan kecenderungan naik (BLH Kota Surabaya, 2012). Laporan Surabaya River Pollution Control Action Plan Study (Binnie \& Partners, 1999) menyatakan bahwa Kali Surabaya menampung beban pencemaran sebesar 75,48 ton limbah per hari, di mana $86 \%$ adalah limbah industri dan $14 \%$ sisanya adalah limbah domestik. Sementara itu, faktor kegiatan manusia dianggap berperan utama dalam menyumbangkan pencemaran sungai. Faktor antropogenik seperti perkembangan pertanian, peningkatan populasi, urbanisasi, industrialisasi dan juga kegagalan kebijakan diidentifikasi sebagai akar penyebab pencemaran air (UNEP, 2006). Berdasarkan sumber-sumber tersebut dapat disimpulkan bahwa secara umum penyebab terjadinya pencemaran sungai berasal dari limbah industri, limbah domestik, perilaku masyarakat dan kegagalan kebijakan.

Faktor-faktor pencemar Kali Surabaya selama ini banyak diungkapkan dalam artikel dan penelitian namun tidak pernah dibandingkan antar faktor tersebut dan dibuktikan faktor mana yang paling berpengaruh terhadap pencemaran air Kali Surabaya. Hal tersebut dapat dilakukan menggunakan menggunakan teknik analisis faktor konfirmatori, yaitu menggunakan teknik analisis statistik multivariat. Analisis multivariat yang memiliki kemampuan untuk menggambarkan keterkaitan hubungan linier secara simultan antara variabel observed dan variabel unobserved adalah Structural Equation Modelling (SEM). Model struktural pada penelitian ini dibentuk oleh konstruk dengan indikator reflektif (arah hubungan dari variabel unobserved ke observed) dan indikator formatif (arah hubungan dari observed ke unobserved). Dalam hal ini Hair dkk. (2011) mengemukakan jika model SEM memiliki konstruk formatif sebaiknya digunakan metode SEM berbasis varians, yaitu Partial Least Square (PLS). Chin dan Newsted (1999) juga merekomendasikan pendekatan PLS ketika teori yang dimiliki masih relatif tentatif atau pengukuran untuk variabel laten adalah baru. Sehingga dalam penelitian ini digunakan PLS-SEM.

Tujuan dari penelitian ini adalah mendapatkan nilai pengaruh dari setiap faktor pencemar air Kali Surabaya yang diprediksi, yaitu kondisi hulu sungai, kondisi air limbah domestik dan persepsi masyarakat. Setelah didapatkan nilai pengaruh masing-masing faktor pencemar, diidentifikasi faktor pencemar mana yang memiliki pengaruh yang paling signifikan dalam mencemari air Kali Surabaya.

\section{METODA}

\section{Lokasi Penelitian}

Penelitian dilakukan di Kali Surabaya sepanjang segmen Gunungsari-Jagir (Gambar 1). Segmen sungai dengan panjang 2,4 kilometer tersebut melewati daerah Gunungsari dan Wonokromo di dalam wilayah Kota Surabaya. Variabel masukan air limbah (point source) berasal dari Pompa Gunungsari I dan Pompa Gunungsari II. Pompa Gunungsari I berada di Kelurahan Sawunggaling, Kecamatan Wonokromo. Pompa ini menyalurkan air dari drainase di Kelurahan Sawunggaling (sekitar Stadion Brawijaya) ke Kali Surabaya di seberang Jalan Raya Gunungsari. Sementara itu Pompa Gunungsari II berada di Kelurahan Gunungsari, Kecamatan Dukuh Pakis. Pompa ini menyalurkan air dari drainase di Kelurahan Gunungsari ke hilir Kali Kedurus yang langsung menuju Kali Surabaya.

Dua wilayah sampling kuesioner ditujukan pada masyarakat yang bermukim di area sekitar kedua point source tersebut. Wilayah tersebut adalah Kelurahan Gunungsari (Pompa Gunungsari II) dan Kelurahan Sawunggaling 
(Pompa Gunungsari I). Selain itu sampling kuesioner juga dilakukan di Kelurahan Wonokromo di dekat Jembatan Wonokromo untuk mewakili area hilir. Dilihat dari sistemnya, selain mendapat masukan air limbah,
Kali Surabaya pada segmen Gunungsari-Jagir juga mendapatkan masukan dari hulu segmen tersebut. Sedangkan keluaran dari sistem tersebut adalah bagian hilir, yaitu di wilayah Jembatan Wonokromo (Dam Jagir).

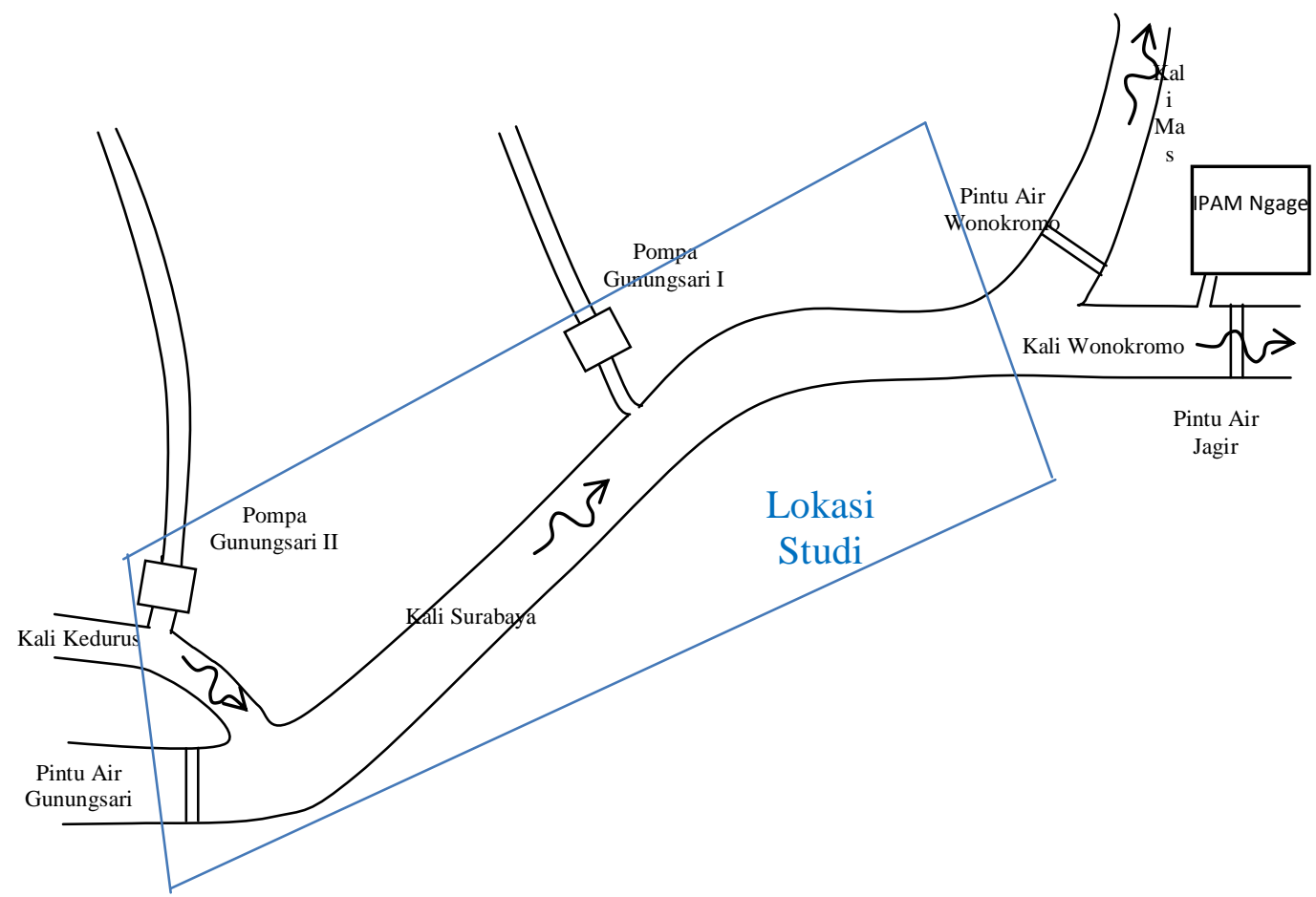

Gambar 1. Denah dan Sistem Kali Surabaya Segmen Gunungsari - Jagir

\section{Identifikasi Variabel}

Variabel dalam penelitian ini merupakan faktorfaktor pencemar yang mempengaruhi Kali Surabaya, yaitu Kondisi Air di Hulu, Kondisi Air Limbah Domestik, Persepsi Masyarakat dan Tingkat Pencemaran Air Kali Surabaya. Penentuan faktor pencemar air didasarkan pada telaahan pustaka dan hipotesis penelitian. Pada SEM dibutuhkan dua jenis variabel laten, yaitu variabel endogen (variabel respon) dan variabel eksogen (variabel prediktor).

Variabel endogen adalah variabel yang nilainya dipengaruhi atau ditentukan oleh variabel eksogen dalam model. Variabel eksogen adalah variabel yang nilainya tidak dipengaruhi atau ditentukan oleh variabel lain di dalam model, dengan kata lain nilainya ditentukan di luar model. Pada konsep model SEM di penelitian ini variabel endogen disimbolkan dengan $\mathrm{Y}$, sedangkan variabel eksogen disimbolkan dengan X. Variabel dalam penelitian ini dirinci dalam Tabel 1.

Penentuan jumlah sampel dilakukan berdasarkan pernyataan Gefen (2000) bahwa sampel minimum analisis PLS adalah setidaknya 10 kali dari jumlah indikator pada konstruk paling kompleks. Maksudnya adalah jumlah sampel minimum untuk penelitian SEMPLS adalah 10 kali jumlah indikator pada suatu variabel laten yang memiliki jumlah indikator paling banyak. Dalam penelitian ini variabel laten yang memiliki indikator paling banyak adalah variabel kondisi hulu, yang mana memiliki 4 indikator. Oleh karena itu jumlah sampel minimum penelitian ini adalah 40 sampel. Dengan pertimbangan data time-series yang didapatkan, jumlah sampel yang digunakan dalam penelitian ini adalah 42 sampel. 
Tabel 1. Variabel Penelitian

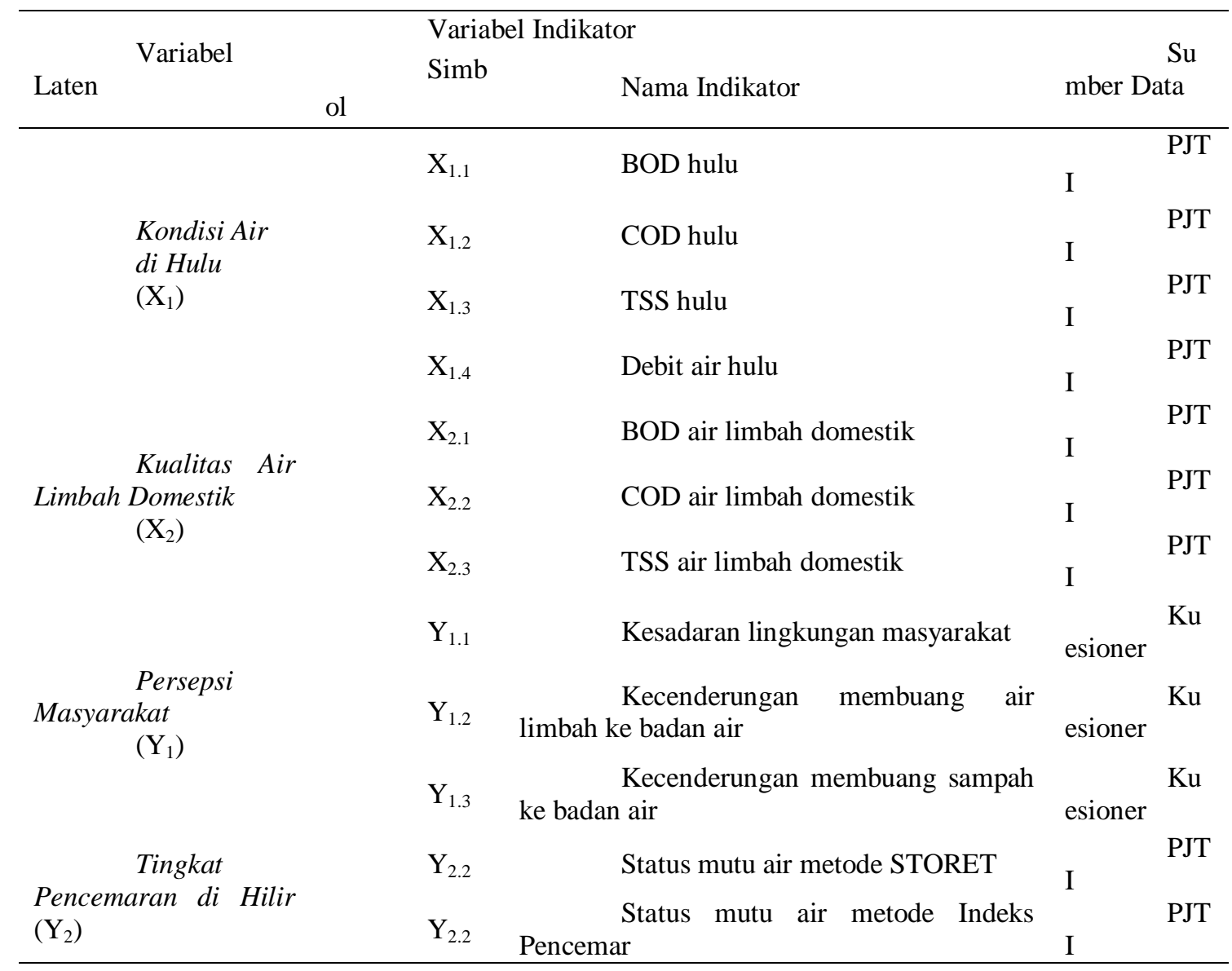

Catatan: PJT I : Perum Jasa Tirta I

\section{Konsep Model}

Dalam metode SEM-PLS, pengukuran variabel laten dapat menggunakan indikator yang bersifat reflektif maupun formatif. Indikator yang bersifat reflektif menyatakan hasil yang diakibatkan oleh variabel laten. Sedangkan indikator yang bersifat formatif menyatakan penyebab atau pembentuk variabel laten. Variabel dalam SEM dibagi menjadi variabel laten dan variabel indikator.

Pada diagram jalur, variabel laten berbentuk elips dan variabel indikator berbentuk kotak. Arah panah dari variabel indikator menuju variabel laten disebut model pengukuran formatif, sebaliknya arah panah dari variabel laten menuju indikator disebut model pengukuran reflektif.

\section{Persamaan Model Pengukuran}

$$
\begin{aligned}
& \underline{\text { Persamaan Model Pengukuran Formatif }} \\
\mathrm{X}_{1}= & \pi_{1} \mathrm{X}_{1.1}+\pi_{2} \mathrm{X}_{1.2}+\pi_{3} \mathrm{X}_{1.3}+\pi_{4} \mathrm{X}_{1.4} \\
\mathrm{Y}_{1}= & \pi_{5} \mathrm{Y}_{1.1}+\pi_{6} \mathrm{Y}_{2.2}+\pi_{7} \mathrm{Y}_{2.3} \\
& \underline{\text { Persamaan Model Pengukuran Reflektif }} \\
\mathrm{X}_{2.1}= & \lambda_{1} \xi_{3}+\delta_{1} \\
\mathrm{X}_{2.2}= & \lambda_{2} \xi_{3}+\delta_{2} \\
\mathrm{X}_{2.3}= & \lambda_{3} \xi_{3}+\delta_{3} \\
\mathrm{Y}_{2.1}= & \lambda_{4} \mathrm{Y}_{2}+\varepsilon_{1} \\
\mathrm{Y}_{2.2}= & \lambda_{5} \mathrm{Y}_{2}+\varepsilon_{2}
\end{aligned}
$$

Keterangan:

$\mathrm{X}_{1.1}-\mathrm{X}_{2.3}=$ indikator dari variabel eksogen

$\mathrm{Y}_{1.1}-\mathrm{Y}_{2.2}=$ indikator dari variabel endogen

$\pi_{1}-\pi_{7}=$ weights loading indikator formatif

$\lambda_{1}-\lambda_{5}=$ loading factor indikator reflektif

$\zeta_{1}-\zeta_{2}=$ error term indikator formatif 
$\delta_{1}-\delta_{6}=$ error term indikator reflektif variabel laten eksogen

$\varepsilon_{1}-\varepsilon_{2}=$ error term indikator reflektif variabel laten endogen

\section{Persamaan Struktural}

$$
\begin{aligned}
& \mathrm{Y}_{1}=\gamma_{12} \mathrm{X}_{2}+\zeta_{1} \\
& \mathrm{Y}_{2}=\gamma_{21} \mathrm{X}_{1}+\gamma_{22} \mathrm{X}_{2}+\beta_{21} \mathrm{Y}_{1}+\zeta_{2}
\end{aligned}
$$

Keterangan:

$$
\gamma_{12}, \gamma_{21}, \gamma_{22}=\text { regression weight konstruk }
$$
eksogen terhadap endogen

$\mathrm{Y}_{1}=$ konstruk endogen kualitas air limbah domestik

$\mathrm{Y}_{2}=$ konstruk endogen tingkat pencemaran air sungai

$\mathrm{X}_{1} \quad=$ konstruk eksogen kondisi air di hulu
$\mathrm{X}_{2}=$ konstruk eksogen persepsi masyarakat

$\zeta_{1}, \zeta_{2}=$ error term model struktural

\section{Persamaan Struktural}

$$
\begin{aligned}
& Y_{1}=\gamma_{12} X_{2}+\zeta_{1} \\
& Y_{2}=\gamma_{21} X_{1}+\gamma_{22} X_{2}+\beta_{21} Y_{1}+\zeta_{2}
\end{aligned}
$$

Keterangan:

$\gamma_{12}, \gamma_{21}, \gamma_{22}=$ regression weight konstruk eksogen terhadap endogen

$\mathrm{Y}_{1}=$ konstruk endogen kualitas air limbah domestik

$\mathrm{Y}_{2}=$ konstruk endogen tingkat pencemaran air sungai

$\mathrm{X}_{1} \quad=$ konstruk eksogen kondisi air di hulu

$\mathrm{X}_{2}=$ konstruk eksogen persepsi masyarakat

$\zeta_{1}, \zeta_{2}=$ error term model struktural

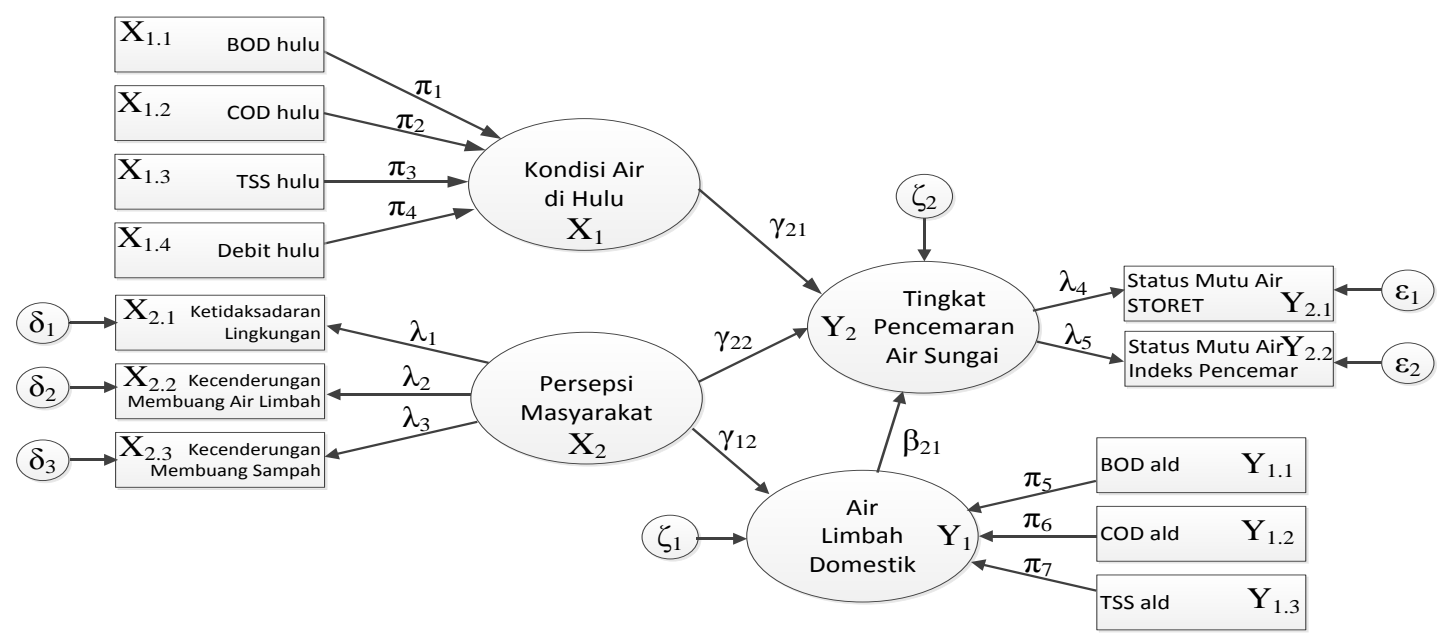

Gambar 2. Diagram Jalur SEM

\section{HASIL DAN PEMBAHASAN}

\section{Kualitas Air Kali Surabaya}

Data kualitas dan debit air hulu didapatkan dari data sekunder, yaitu dari hasil pemantauan rutin Perum Jasa Tirta I (PJT I). Hulu dari wilayah studi yang dimaksud adalah inflow dari Dam Gunungsari. Parameter hulu yang diteliti adalah BOD, COD, TSS dan debit alirannya. Penelitian ini mengambil 42 sampel, sehingga data kualitas dan debit air Kali Surabaya yang digunakan adalah data tahun 2010 bulan Januari hingga
2013 bulan Juni (selama 3,5 tahun). Data kualitas dan debit air di Dam Gunungsari ditunjukkan oleh Gambar 3, Gambar 4 dan Gambar 5.

\section{Kualitas Air Limbah Domestik}

Data kualitas air limbah domestik diambil dari data sekunder, yaitu sampling air oleh PJT I selama bulan Oktober hingga November 2013. Sampling air dilakukan di point sources berupa pompa banjir di daerah Gunungsari, yaitu Pompa Gunungsari I dan Pompa Gunungsari II. 


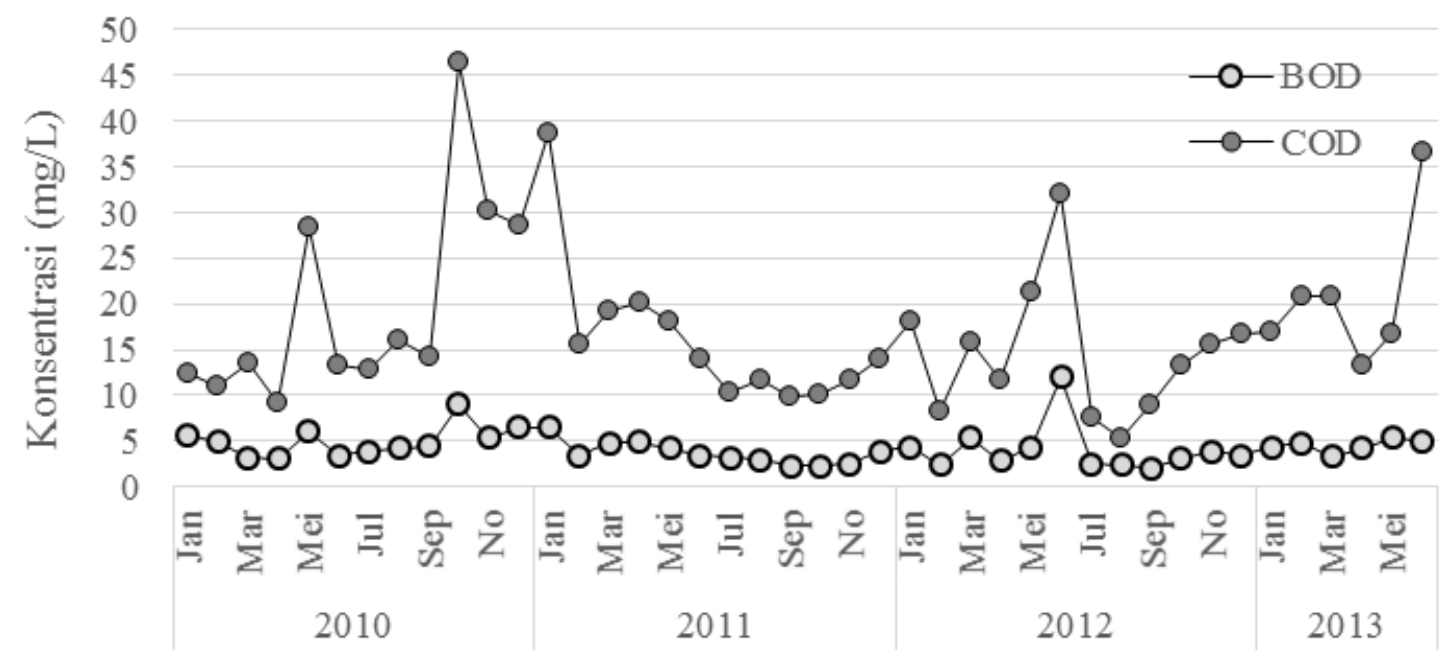

Gambar 3. BOD dan COD di Dam Gunungsari

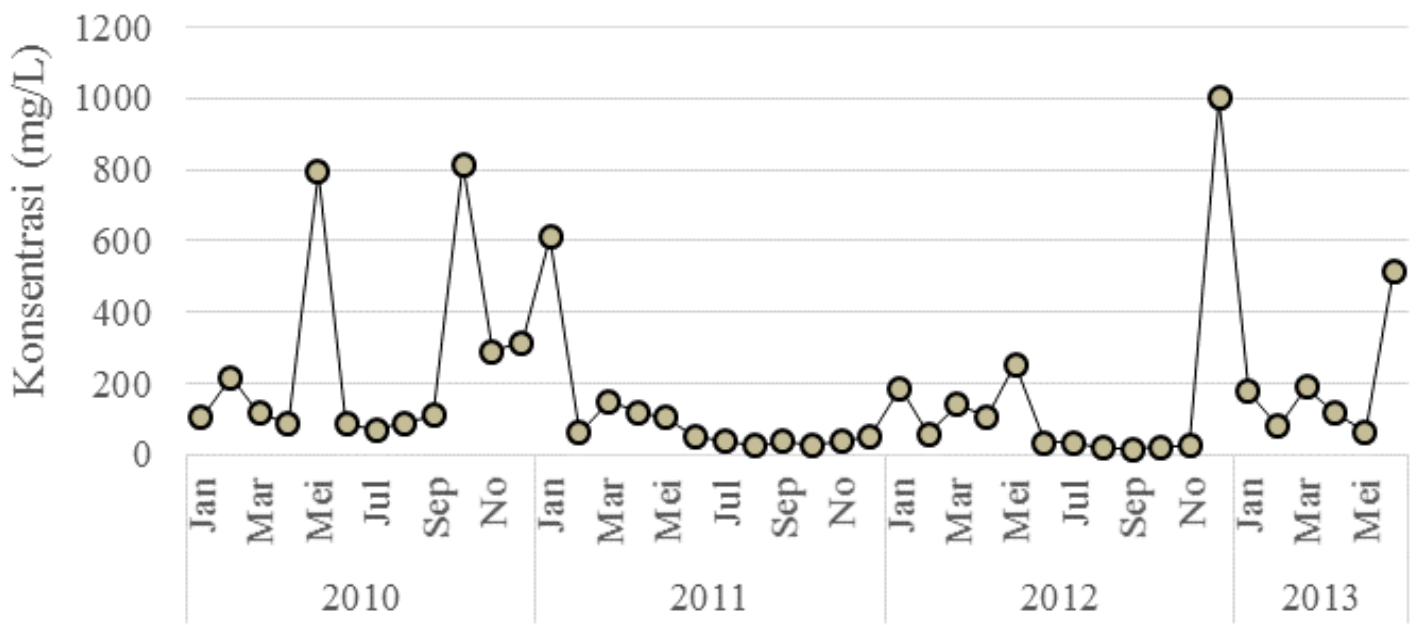

Gambar 4. TSS di Dam Gunungsari

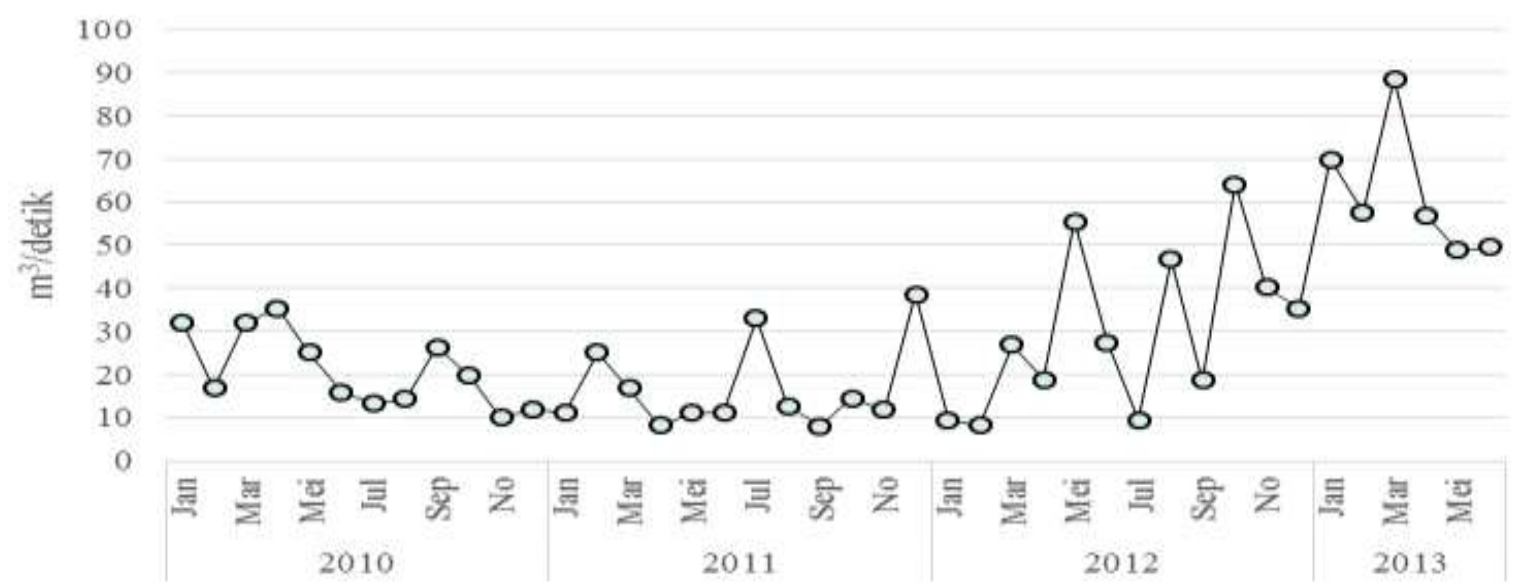

Gambar 5. Debit di Dam Gunungsari 


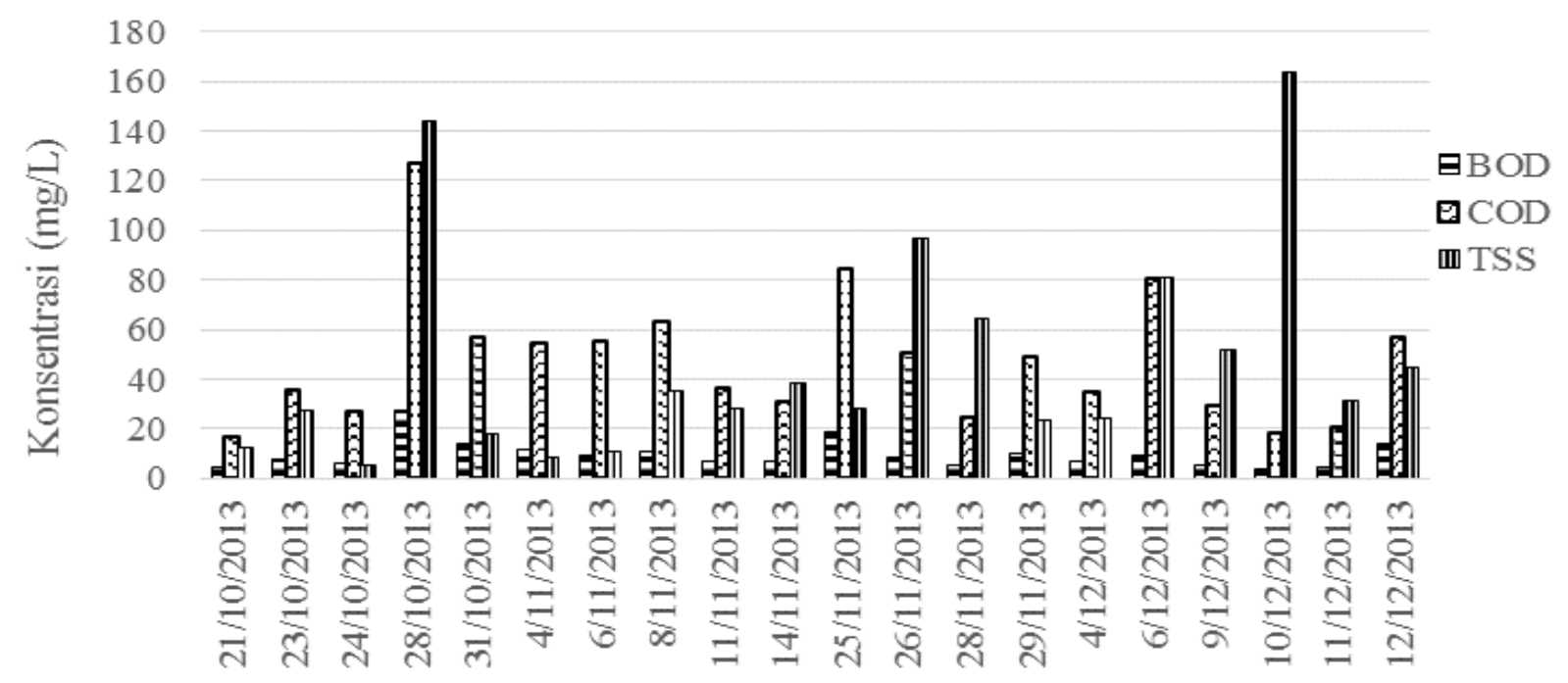

Gambar 6. BOD, COD dan TSS di Pompa Gunungsari I

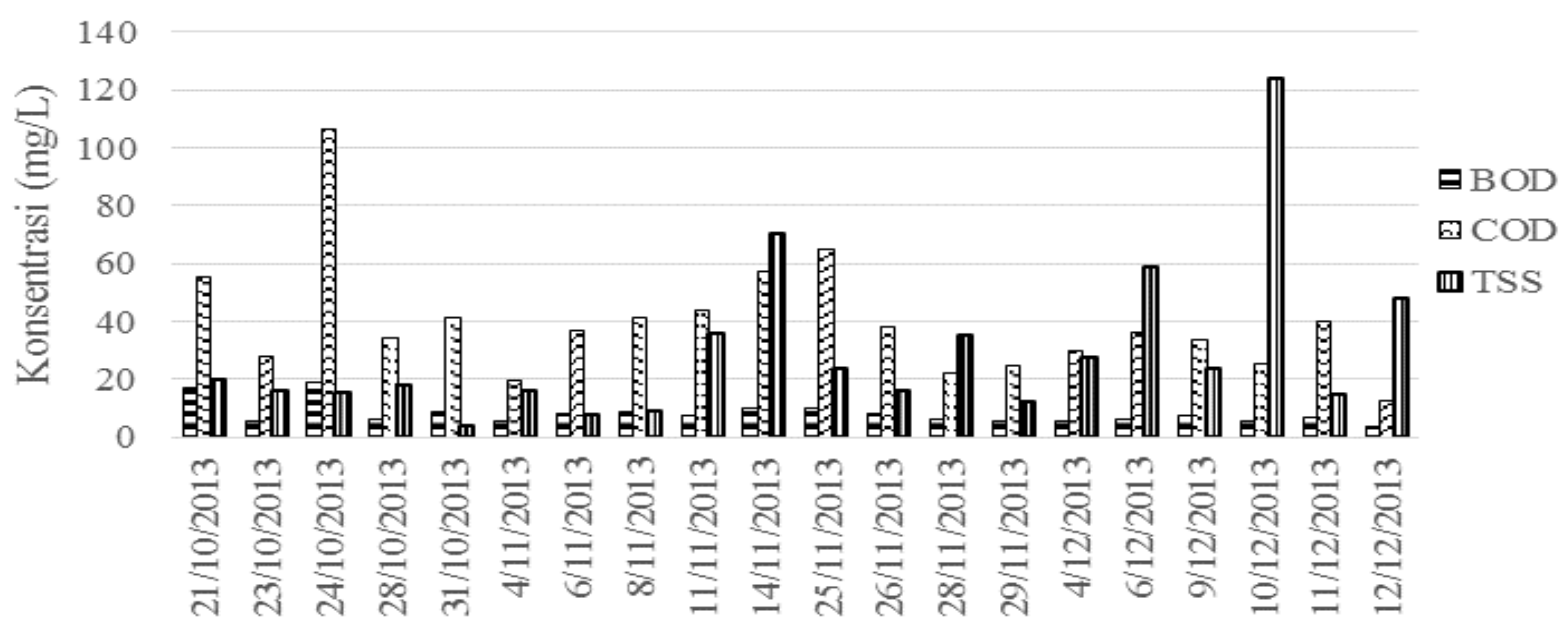

Gambar 7. BOD, COD dan TSS di Pompa Gunungsari II

\section{Persepsi Masyarakat}

Hasil kuesioner yang ditunjukkan oleh Gambar 8 menunjukkan bahwa kesadaran lingkungan di masyarakat bantaran Kali Surabaya rata-rata sudah tinggi. Kesadaran lingkungan tersebut ditunjukkan oleh hal-hal berikut ini. Warga telah menyadari bahwa pihak yang bertanggungjawab terhadap kebersihan lingkungan di sekitar mereka adalah mereka sendiri (sebanyak 54,8\% sangat setuju dan $42,9 \%$ setuju). Sebagian besar warga terlibat dalam kegiatan masyarakat di lingkungan tempat tinggalnya $(97,6 \%)$.

Sebagian besar warga telah mengetahui setidaknya aturan lingkungan seperti pelarangan membuang sampah ke sungai $(95,2 \%)$. Sebagian besar warga juga mengetahui fungsi air sungai Kali Surabaya, yaitu untuk memasok air baku untuk PDAM $(88,1 \%)$. Persepsi ini penting dengan asumsi bahwa jika warga mengetahui fungsi air Kali Surabaya, maka warga akan ikut menjaga kualitas air 
sungai. Sebagian besar warga memang memperhatikan kondisi sungai Kali Surabaya (81\%) dan menganggap bahwa kondisi Kali Surabaya akan mempengaruhi kehidupan di tempat tinggalnya $(64,3 \%)$. Sementara itu warga juga tidak pernah memanfaatkan air dari sungai Kali Surabaya secara langsung untuk kebutuhan sehari-hari $(83,3 \%)$.

Semua hal ini menyimpulkan bahwa kesadaran lingkungan warga di sekitar bantaran Kali Surabaya segmen Gunungsari-Jagir, tergolong cukup tinggi. Kecenderungan masyarakat untuk membuang air limbah domestik ke sungai tergolong dalam tingkatan "sedang" (79\% dari warga). Hal ini disebabkan masyarakat tidak memiliki pilihan lain dalam membuang air limbah greywater selain ke saluran air. Sedangkan untuk air limbah blackwater tidak menjadi ancaman lagi bagi segmen sungai di lokasi penelitian, karena rata-rata masyarakat telah memiliki septic tank. Terlebih di Kelurahan Wonokromo, sudah terdapat jamban umum yang dilengkapi dengan septic tank dan sumur resapan.

Kecenderungan masyarakat untuk membuang sampah ke sungai tergolong rendah (60\%). Kecenderungan yang rendah ditunjukkan terutama oleh Kelurahan Gunungsari yang telah memiliki Bank Sampah dan pernah dibantu pengelolaan sampahnya oleh Program Nasional Pemberdayaan Masyarakat (PNPM) Mandiri. Selain itu, dari hasil wawancara langsung di Kelurahan Wonokromo, diketahui dua hal. Pertama, kesadaran masyarakat untuk tidak membuang sampah ke sungai sebenarnya sudah cukup baik, terutama pada warga penduduk asli Surabaya. Kedua, kebanyakan warga yang masih sulit disadarkan adalah pendatang. Sementara itu tidak terdapat pengelolaan sampah khusus di Kelurahan Sawunggaling.

Wonokromo rata-rata tercemar ringan. Pada metode Indeks Pencemar, mutu air tercemar sedang pada bulan Maret, April, Mei dan Juni. Data yang dimasukkan sebagai indikator dari variabel tingkat pencemaran Kali Surabaya di dalam model SEM adalah hasil skor STORET dan nilai indeks pencemar. Skor STORET menggunakan nilai negatif, sehingga perlu dijadikan positif terlebih dahulu agar sesuai dengan indikator lainnya.

\section{Status Mutu Air di Hilir}

Status mutu air dianalisis berdasarkan Keputusan Menteri Lingkungan Hidup Nomor 115 Tahun 2003 tentang Pedoman Status Mutu Air. Dalam pedoman tersebut terdapat dua metode untuk menentukan status mutu air, yaitu metode STORET dan metode Indeks Pencemaran. Segmen sungai yang dianalisis status mutu airnya pada penelitian ini adalah pada hilir sungai, yakni pada lokasi sampling dekat Jembatan Wonokromo. Penentuan status mutu air menggunakan parameter kualitas air sungai BOD, COD, TSS, DO, $\mathrm{NO}_{3}$ dan $\mathrm{NH}_{3}$. Pada perhitungan skoring dengan metode STORET ditemukan bahwa mutu air di Jembatan Wonokromo rata-rata tercemar sedang. Pada metode STORET, mutu air tercemar berat pada bulan-bulan Maret, April dan Mei. Pada perhitungan metode Indeks Pencemar ditemukan bahwa mutu air di Jembatan

\section{Evaluasi Outer Model}

Evaluasi model dilakukan menggunakan program SmartPLS 2.0 M3. Model yang dihasilkan oleh SmartPLS 2.0 M3 dapat dilihat pada Gambar 9. Gambar tersebut merupakan model hasil evaluasi outer model. Evaluasi outer model adalah pengujian model pengukuran (measurement model) tiap konstruk variabel laten. Pada pengujian outer model untuk indikator reflektif yang diuji adalah validitas dan reliabilitas datanya. Sedangkan pada pengujian outer model untuk indikator formatif yang diuji adalah signifikansi weight loading dan keberadaan multikolinearitas. Pada penelitian ini terdapat variabel dengan indikator formatif, yaitu kondisi air hulu dan kualitas air limbah domestik. Walaupun begitu, data yang digunakan untuk indikator formatif dalam 


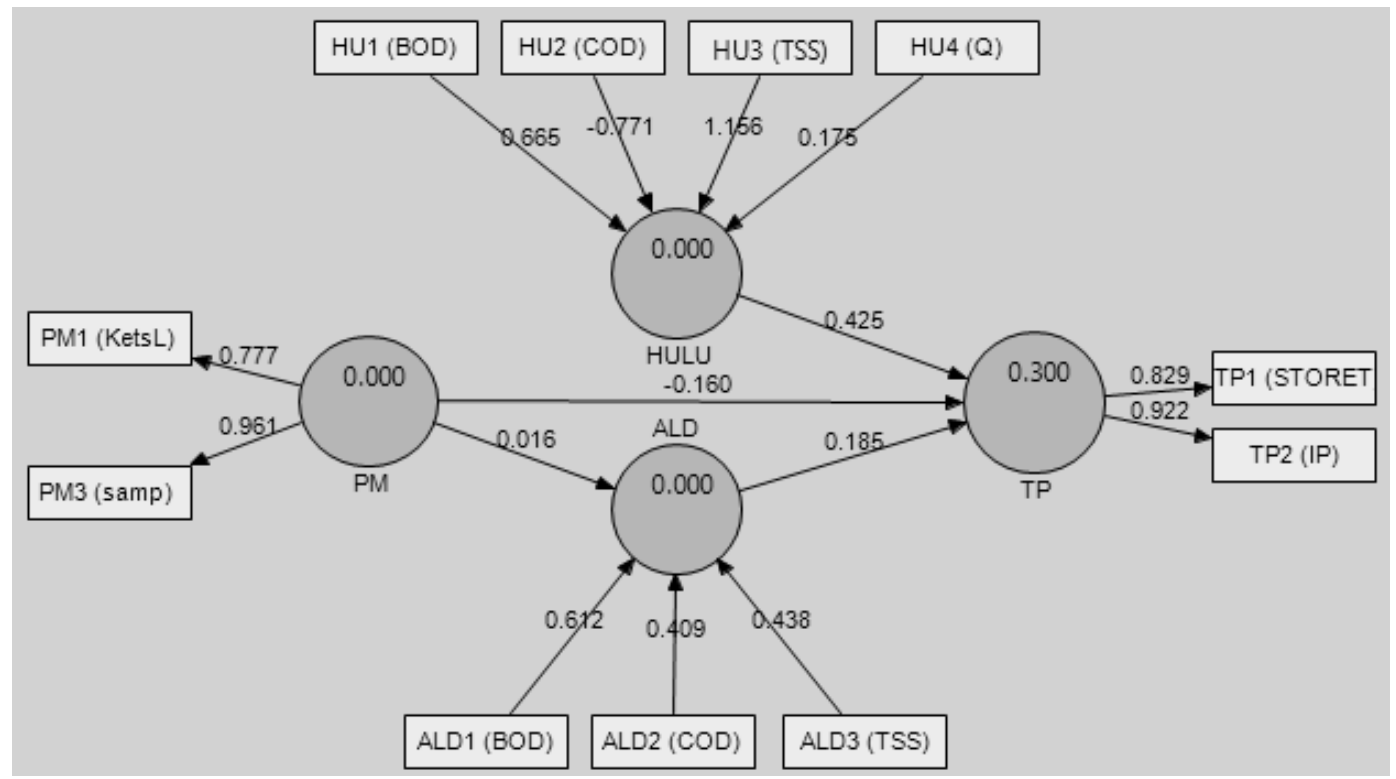

Gambar 8. Model Output SmartPLS

penelitian ini menggunakan data asli. Data kualitas air yang didapatkan telah melalui prosedur pengujian di laboratorium untuk menjamin validitasnya. Oleh karena itu, pada penelitian ini pengujian outer model hanya meliputi indikator variabel reflektif, yaitu hanya variabel persepsi masyarakat.

Validitas outer model indikator reflektif diuji melalui validitas konvergen dan validitas diskriminan. Pengujian validitas konvergen menuntut nilai loading factor hubungan indikator dengan variabel laten lebih besar dari 0,50 (Ghozali, 2008) dan nilai Average Variance Extracted (AVE) di atas 0,50 (Latan dan Ghozali, 2012). Pada penelitian ini terdapat satu indikator pada variabel persepsi masyarakat yang nilainya kurang dari 0,5 , yaitu indikator kecenderungan membuang air limbah ke badan air. Sehingga indikator tersebut harus dihapus dari model.

Setelah indikator Kualitas Air Limbah Domestik dibuang, dilanjutkan pengujian validitas diskriminan dengan melihat nilai cross loading dan juga membandingkan akar kuadrat AVE dengan korelasi antar variabel laten. Nilai cross loading dapat dilihat pada Tabel 3, sedangkan akar kuadrat AVE dan korelasi antar variabel laten dapat dilihat pada Tabel 4 dan Tabel 5, secara berurutan. Hasilnya, diketahui bahwa seluruh indikator reflektif memiliki nilai cross loading lebih dari 0,70 dan nilai akar kuadrat AVE lebih besar dari korelasi variabel laten. Hal ini berarti indikator reflektif yang diuji telah valid. Dilakukan uji reliabilitas indikator reflektif dengan melihat nilai cronbach's alpha dan composite reliability (Tabel 2). Nilai cronbach's alpha dan composite reliability sudah berada di atas 0,7 , sehingga dapat disimpulkan variabel persepsi masyarakat dan tingkat pencemaran reliabel. Dengan ini seluruh variabel dengan indikator reflektif telah valid dan reliabel. Pada penelitian ini indikator formatif tidak dilakukan pengujian validitas dan reliabilitas sehingga evaluasi model dilanjutkan pada inner model.

\section{Evaluasi Inner Model}

Setelah pengujian model pengukuran (outer model) terpenuhi, selanjutnya dilakukan pengujian terhadap model struktural (inner model). Evaluasi model struktural atau inner model bertujuan untuk memprediksi hubungan antar variabel laten. Kekuatan prediksi dari model struktural dilihat dari nilai $\mathrm{R}^{2}$ setiap 
variabel laten endogen. Nilai $\mathrm{R}^{2}$ sebesar 0,75 , 0,50 dan 0,25 menerangkan kekuatan model, secara berurutan adalah kuat, moderate dan lemah (Hair dkk., 2011). Setelah dilakukan pengujian nilai $\mathrm{R}^{2}$, evaluasi model dilanjutkan dengan melihat nilai signifikansi weight, yaitu melihat nilai t-statistik.

Nilai t-statistik akan keluar jika model telah dibootstrap. Nilai t-statistik lebih besar dari 1,96 menunjukkan bahwa variabel laten tersebut signifikan pada tingkat signifikansi $\alpha=0,05$.
Bootstrapping dilakukan dengan jumlah case (jumlah data) sebanyak 42 dan jumlah resampling 100 kali.

Sebelumnya banyaknya resample ditentukan dengan melakukan trial bootstrapping pada 100, 200, 300, 400, 500, 600, 700, 800, 900 dan 1000 resample. Bootstrapping dengan 100 resample dipilih sebab nilai koefisien jalurnya paling mendekati dengan nilai koefisien awal. Diagram jalur hasil bootstrapping 100 resample ditampilkan pada Gambar 9.

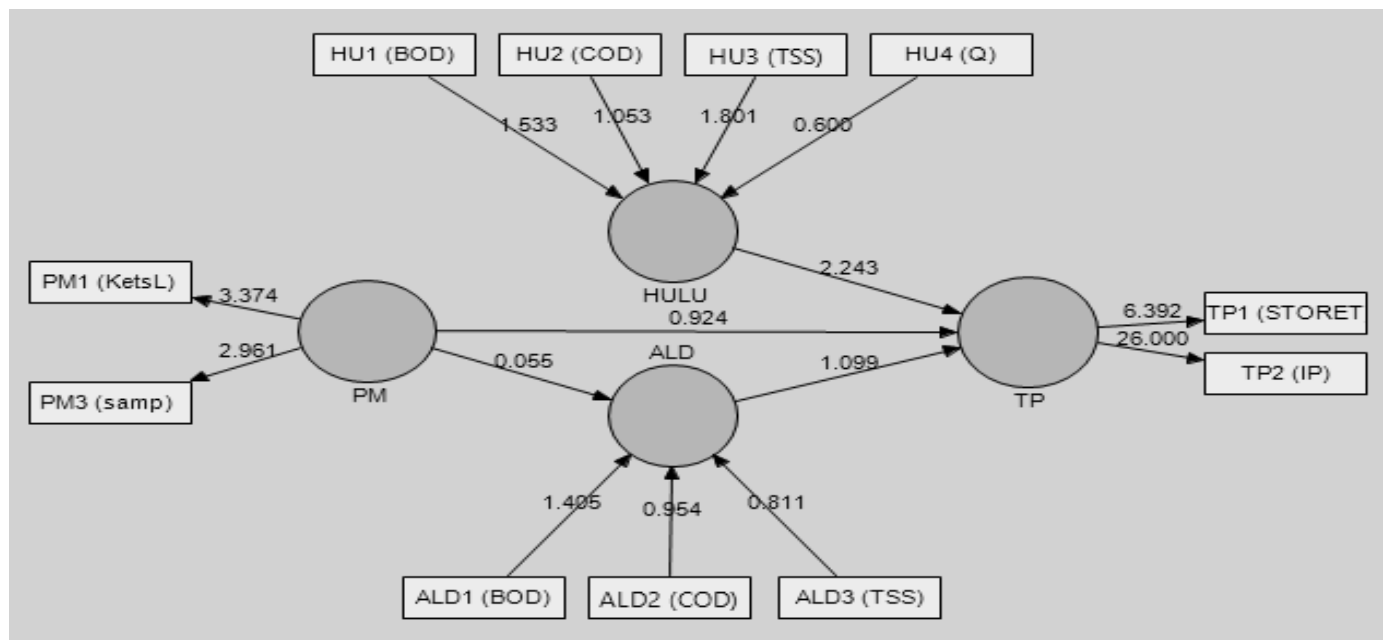

Gambar 9. Model Output SmartPLS Hasil Bootstrapping 100 Resample

Tabel 2. AVE, Composite Reliability, Cronbachs Alpha dan $\mathrm{R}^{2}$

\begin{tabular}{lllll}
\hline & AVE & $\begin{array}{l}\text { Composite } \\
\text { Reliability }\end{array}$ & $\begin{array}{l}\text { Cronbachs } \\
\text { Alpha }\end{array}$ & $\boldsymbol{R}^{2}$ \\
\hline HULU & - & - & - & - \\
ALD & - & - & - & 0,0002 \\
$P M$ & 0,7630 & 0,8642 & 0,7269 & - \\
$T P$ & 0,7685 & 0,8688 & 0,7076 & 0,2996 \\
\hline
\end{tabular}

Tabel 3. Cross Loadings

\begin{tabular}{lll}
\hline & $\boldsymbol{P M}$ & $\boldsymbol{T P}$ \\
\hline PM1 & 0,7767 & $-0,1146$ \\
PM3 & 0,9606 & $-0,2607$ \\
$T P 1$ & $-0,2343$ & 0,8291 \\
$T P 2$ & $-0,1950$ & 0,9218 \\
\hline
\end{tabular}

Tabel 4. Nilai Akar Kuadrat AVE

\begin{tabular}{lll}
\hline & AVE & VAVE \\
\hline$P M$ & 0,763 & 0,874 \\
$T P$ & 0,769 & 0,877 \\
\hline
\end{tabular}

Tabel 5. Korelasi Antar Variabel

\begin{tabular}{lllll}
\hline Laten & ALD & HULU & $P M$ & $T P$ \\
\hline$P M$ & 0,016 & $-0,192$ & 1,000 & - \\
& & & & \\
$T P$ & 0,274 & 0,496 & $-0,239$ & 1,000 \\
\hline
\end{tabular}


Tabel 6. Path Coefficients

\begin{tabular}{lllll}
\hline & $\begin{array}{l}\text { Original } \\
\text { Sample } \\
\text { O }\end{array}$ & $\begin{array}{l}\text { Sample } \\
\text { Mean }\end{array}$ & $\begin{array}{l}\text { Standard } \\
\text { Error } \\
\text { STERR }\end{array}$ & $\begin{array}{l}\text { T Statistics } \\
\text { |O|/STERR }\end{array}$ \\
\hline$A L D$ & 0,185 & 0,215 & 0,169 & 1,099 \\
$\rightarrow T P$ & & & & \\
$H U L U \rightarrow$ & 0,425 & 0,466 & 0,190 & 2,243 \\
$T P$ & & & & \\
$P M$ & $\rightarrow 0,016$ & $-0,078$ & 0,286 & 0,055 \\
$\begin{array}{l}A L D \\
P M\end{array}$ & $-0,160$ & $-0,129$ & 0,173 & 0,924 \\
$\rightarrow T P$ & & & & \\
\hline
\end{tabular}

Berdasarkan Tabel 2, nilai $\mathrm{R}^{2}$ variabel endogen tingkat pencemaran adalah 0,2996. Hal ini berarti model struktural penelitian dianggap lemah. Sementara itu, setelah bootstrapping dilakukan, nilai t-statistik dapat dilihat pada output SmartPLS yang berjudul path coefficients (Tabel 6). Nilai t-statistik tersebut merupakan nilai t-hitung yang didapatkan dari membagi nilai koefisien jalur asli (sebelum dibootstrap) dengan nilai standard error. Berdasarkan Tabel 5, variabel yang signifikan (dengan tingkat kepercayaan 95\%) hanyalah kondisi hulu, disebabkan hanya variabel tersebut yang memiliki nilai t-hitung lebih dari 1,96.

Berikut penjelasan terhadap interpretasi nilai tstatistik yang terdapat pada Tabel 6:

1. Koefisien jalur yang diperoleh dari hubungan antara variabel kualitas air limbah domestik dengan variabel tingkat pencemaran adalah sebesar 0,215 dengan nilai t-hitung sebesar 1,099. Nilai t-hitung tersebut lebih kecil dari 1,96 $(\alpha=0,05)$ maupun 1,64 $(\alpha=0,10)$. Sehingga dapat dinyatakan bahwa pengaruh air limbah domestik terhadap tingkat pencemaran tidak signifikan.

2. Koefisien jalur yang diperoleh dari hubungan antara variabel kondisi hulu dengan variabel tingkat pencemaran adalah sebesar 0,466 dengan nilai t-hitung sebesar 2,243. Nilai t-hitung tersebut lebih besar dari 1,96 $(\alpha=0,05)$. Sehingga dapat dinyatakan bahwa kondisi hulu berpengaruh signifikan terhadap tingkat pencemaran.
3. Koefisien jalur yang diperoleh dari hubungan antara variabel persepsi masyarakat dengan variabel tingkat pencemaran adalah sebesar $-0,078$ dengan nilai t-hitung sebesar 0,924. Nilai t-hitung tersebut lebih kecil dari 1,96 $(\alpha=0,05)$ maupun 1,64 $(\alpha=0,10)$. Sehingga dapat dinyatakan bahwa pengaruh persepsi masyarakat terhadap tingkat pencemaran tidak signifikan. Nilai negatif menyatakan bahwa bila persepsi masyarakat terhadap lingkungan meningkat akan menurunkan tingkat pencemaran.

4. Koefisien jalur yang diperoleh dari hubungan antara variabel persepsi masyarakat dengan variabel kualitas air limbah domestik adalah sebesar 0,016 dengan nilai t-hitung sebesar 0,055 . Nilai thitung tersebut lebih kecil dari 1,96 $(\alpha=0,05)$ maupun 1,64 $(\alpha=0,10)$. Sehingga dapat dinyatakan bahwa pengaruh persepsi masyarakat terhadap air limbah domestik tidak signifikan.

\section{Interpretasi Model}

Variabel air limbah domestik dan persepsi masyarakat disimpulkan sebagai faktor pencemar yang pengaruhnya tidak signifikan dalam meningkatkan pencemaran Kali Surabaya. Sedangkan kondisi air di hulu Kali Surabaya disimpulkan sebagai faktor yang paling berkontribusi terhadap pencemaran air Kali Surabaya.

Hal ini masuk akal mengingat di hulu segmen Kali Surabaya yang menjadi lokasi studi terdapat banyak industri. Oleh sebab itu pengendalian pencemaran air Kali Surabaya sebaiknya lebih difokuskan kepada pengendalian air limbah di hulu, khususnya air limbah industri. Berdasarkan Tabel 6, dapat diketahui nilai koefisien jalur model. Koefisien jalur tersebut merupakan besaran pengaruh dari satu variabel ke variabel lain. Sehingga diketahui bahwa:

- besarnya pengaruh langsung kondisi hulu terhadap tingkat pencemaran adalah 0,215 ; 
- besarnya pengaruh langsung kondisi air limbah domestik terhadap tingkat pencemaran adalah 0,466 ; dan

- besarnya pengaruh langsung persepsi masyarakat terhadap tingkat pencemaran adalah $-0,129$.

Sehingga persamaan strukturalnya adalah:

Tingkat Pencemaran $=0,215 \times$ Kondisi Hulu + 0,466 × Kualitas Air Limbah Domestik $0,129 \times$ Persepsi Masyarakat

Interpretasi persamaan struktural tersebut untuk penelitian ini adalah:

a) Setiap kondisi hulu (kualitas BOD, COD, TSS dan debit) naik satu satuan, maka tingkat pencemaran Kali Surabaya akan cenderung meningkat sebesar 0,215 kali.

b) Setiap kualitas air limbah domestik (BOD, COD, TSS) naik satu satuan, maka tingkat pencemaran Kali Surabaya akan cenderung meningkat sebesar 0,466 kali.

c) Setiap persepsi masyarakat terhadap pengelolaan lingkungan meningkat sebesar satu satuan, maka tingkat pencemaran Kali Surabaya akan cenderung menurun sebesar 0,129 kali.

\section{KESIMPULAN}

Penelitian dengan menggunakan Structural Equation Modelling (SEM) berbasis varians dapat digunakan dalam penilaian faktor pencemaran. Hasil dari penelitian ini dinyatakan dalam pengaruh faktor pencemaran terhadap tingkat pencemaran Kali Surabaya. Setiap kondisi hulu (kualitas BOD, COD, TSS dan debit) naik satu satuan, maka tingkat pencemaran Kali Surabaya akan cenderung meningkat sebesar 0,215 kali.

Setiap kualitas air limbah domestik (BOD, COD, TSS) naik satu satuan, maka tingkat pencemaran Kali Surabaya akan cenderung meningkat sebesar 0,466 kali. Setiap persepsi masyarakat terhadap pengelolaan lingkungan meningkat sebesar satu satuan, maka tingkat pencemaran Kali Surabaya akan cenderung menurun sebesar 0,129 kali. Hasil pengujian inner model menyatakan bahwa faktor yang memiliki pengaruh yang signifikan terhadap pencemaran air Kali Surabaya di segmen Gunungsari-Jagir adalah kondisi hulu.

\section{UCAPAN TERIMA KASIH}

Terima kasih kepada beasiswa Fresh Graduate Institut Teknologi Sepuluh Nopember. Dana studi program Magister Teknik Lingkungan Institut Teknologi Sepuluh Nopember yang dijalani penulis dari tahun ajaran 2012/2013 hingga 2013/2014 diberikan oleh beasiswa Fresh Graduate Institut Teknologi Sepuluh Nopember.

\section{DAFTAR PUSTAKA}

Badan Lingkungan Hidup Kota Surabaya .2012. Laporan Status Lingkungan Hidup Kota Surabaya 2011. BLH Kota Surabaya, Surabaya.

Binnie \& Partners Ltd. 1999. Surabaya River Pollution Control Action Plan Study. Vol. 2, Main Report. Redhill, UK.

Chin, W.W. dan Newsted, P.R. 1999. "Structural Equation Modeling Analysis with Small Samples Using Partial Least Squares", dalam Statistical Strategies for Small Sample Research, R. Hoyle (Ed.), hal. 307-341, Sage Publications, Thousand Oaks (California).

Gefen, D., Straub, D.W. dan Boudreau M.C. 2000. "Structural Equation Modeling and Regression: Guidelines for Research Practice, Communications of the Association for Information Systems, Vol. 4, No. 7.

Hair, J.F., Ringle, C.M. dan Sarstedt, M. 2011. "PLS-SEM: Indeed a Silver Bullet", Journal of Marketing Theory and Practice, Vol. 19, No. 2, hal. 139-151.

Keputusan Menteri Lingkungan Hidup No.115 Tahun 2003. 2003. Penentuan Status Mutu Air dengan Metode Indeks Pencemaran. 
Latan, H. dan Ghozali, I. 2012. Partial Least Squares Konsep, Teknik dan Aplikasi Menggunakan Program SmartPLS 2.0 M3. Badan Penerbit Universitas Diponegoro, Semarang.

Masduqi, A. dan Apriliani, E. 2008. "Estimation of Surabaya River Water Quality Using
Kalman Filter Algorithm", IPTEK The Journal for Technology and Science, Vol. 19, No. 3, hal. 87-91.

UNEP .2006. "Challenge to International Waters - Regional Assessments in a Global Perspective" dalam United Nations Environment Programme, Nairobi, Kenya. 